\title{
Effects of Dietary Protein Level and Phase Feeding Regimen on Growth Performance, Carcass Characteristics and Pork Quality in Growing-finishing Pigs
}

Jae Young Choi, Prashant Shinde, Zheng Jin, Jin Soo Kim and Byung Jo Chae*

College of Animal Resources Science, Kangwon National University

\begin{abstract}
Two experiments were conducted to study the effects of dietary protein level and phase feeding regimens on performance, carcass characteristics and pork quality in growing-finishing pigs. In both experiments, growing pigs ( $\mathrm{n}=90$; barrows; Landrace $\times$ Yorkshire $\times$ Duroc) were allotted to 3 treatments. Each treatment had 3 replicate pens comprising 10 pigs in each. In Exp. 1, pigs (average body weight $25.06 \pm 0.57 \mathrm{~kg}$ ) were fed diets having low (17.50-14.50-12.51\%), medium (19.49-17.50-13.87\%) or high (22.47-19.49-16.36\%) CP concentration (LP, MP and HP diets, respectively) diets during grower-finisher I-finisher II phases, respectively. Feeding of MP diet resulted in higher $(\mathrm{P}<0.05)$ ADG and better FCR than pigs fed LP diet. Pigs fed HP diet had lower $(\mathrm{P}<0.05)$ pork color and marbling score. Meat of pigs fed LP diet had higher $(\mathrm{P}<0.05)$ Thiobarbituric acid reactive substances (TBARS), while meat of pigs fed HP and LP diets had greater drip loss than pigs fed MP diet. In addition, meat from pigs fed LP diet was darker while meat of pigs fed HP and MP diets was paler and redder. In Exp. 2, pigs (average body weight $10.40 \pm 0.61 \mathrm{~kg}$ ) were subjected during 126 days to three or four phase regimes of different duration. The treatments T1 and T2 were subjected to four phase feeding regimens (grower I, grower II, finisher I and finisher II) for 22, 42,32 and 30 days (T1) and 40, 40, 25 and 21 days (T2), respectively, while T3 was subjected to three phase feeding regimen (grower I, grower II and finisherI) for 40, 56 and 30 days, respectively. Duration of phase feeding regimens had no effect (P>0.05) on the performance, carcass traits and meat quality of pigs. These results suggest that both high and low levels of CP have a negative effect on performance and pork quality; however, alterations in the phase feeding regimens do not have any discernible effect on the performance and pork quality in growing-finishing pigs.
\end{abstract}

(Key words : Phase feeding, Protein levels, Performance, Carcass characteristics, Growing-finishing pigs)

\section{INTRODUCTION}

Feeding diets containing excessive protein to pigs is not only wasteful and expensive, but also results in greater nitrogen excretion. Reduction of dietary crude protein (CP) by 3 to 4 percentage units and amino acid supplementation decreased total $\mathrm{N}$ excretion by approximately 28 to $36 \%$ (Sutton et al., 1996). Phase feeding refers to feeding programs that match the growing animal's changing nutritional requirement with the animal's age/size, and physiological status. Currently, the practice of three phase feeding of growing-fattening pigs is used for better growth performance, reduce feed cost (Ko et al., 2003), and environmental pollution (Han et al., 2001). Commercial swine farms follow two phase feeding for finishing pigs as suggested by NRC (1998). The requirement of protein and amino acids change rapidly during finishing period and the efficiency of nutrient utilization is dramatically decreased after $90 \mathrm{~kg}$ body weight. Thus, feeding system involving multiple phases needs to be considered for finishing pigs.

Previous studies in pigs offered choice of diets differing in protein levels reported the ability of pigs to adjust their protein intake so as to meet their requirement (Kyriazakis et al., 1990). However, later a series of studies showed that pigs do not have the ability to adjust their protein intake to meet their requirement when provided a choice of isoenergetic diets differing in protein content (Owen et al., 1994; Nam and Aherne, 1995). In a study to optimize the number of regimens in phase feeding and dietary $\mathrm{CP}$, it was noticed that pigs fed three or four phase regimes reached market weight early and the backfat thickness tended to decrease with an increase in the number of phase feeding regimes (Lee et al., 2000). However, there are inconsistencies in the reported findings on effects of dietary protein levels and also of phase feeding regimens on the carcass characteristics (Lee et al., 2000; 2001a,b; Ko et al., 2004). Thus the present study was conducted to evaluate and optimize the levels of dietary CP during phase feeding

* Corresponding author: B. J. Chae, Department of Animal Resources Science, Kangwon National University, Chuncheon 200-701, Korea. Tel: 033-250-8616, Fax: 033-244-4946, E-mail: bjchae@kangwon.ac.kr 
regimen (Exp. 1) and duration and number of phase feeding regimens (Exp. 2) on the performance, carcass characteristics and meat quality in growing-finishing pigs.

\section{MATERIALS AND METHODS}

\section{Experimental design, animals, housing and diets}

In Exp. 1, a total of 90 crossbred growing barrows (Landrace $\times$ Yorkshire $\times$ Duroc; average body weight $25.06 \pm$ $0.57 \mathrm{~kg}$ ) were randomly allotted to three dietary treatments based on body weight. Each treatment was replicated three times with ten pigs in each replicate. Growing-finishing period (25 to $110 \mathrm{~kg}$ ) was divided into three phases (grower, 25 to $55 \mathrm{~kg}$; finisher I, 55 to $85 \mathrm{~kg}$; finisher II, 85 to 110 kg). Dietary treatments were: high dietary CP with 22.4719.49-16.36\%; medium dietary CP with 19.49-17.50-13.87\% and low dietary CP with 17.50-14.50-12.51\%(HP, MP and
LP, respectively), offered during grower-finisher I-finisher II phases, respectively. The ingredient and calculated nutrient composition of experimental diets is presented in Table 1.

Experiment 2 was designed to evaluate the effect of different duration and number of phase feeding regimens. A total of 90 crossbred barrows (Landrace $\times$ Yorkshire $\times$ Duroc; average body weight $10.40 \pm 0.61 \mathrm{~kg}$ ) were allotted to different durations and number of phase feeding regimens. Each treatment comprised three replicates with ten pigs in each replicate. Experimental feeding was conducted for 126 days in three or four phases (Table 2). Treatments were: T1 fed for duration of 22, 42, 32 and 30 days and T2 fed for duration of $40,40,25$, and 21 days with grower I, grower II, finisher I and finisher II diets, respectively; whereas, T3 was fed for 40, 56 and 30 days with grower I, grower II and finisher I diets, respectively. Experimental diets were formulated to contain 3,300 kcal/kg ME and $22.47 \% \mathrm{CP}$ for grower I diet, 3,300 kcal/kg ME and 19.49\% CP for grower

Table 1. Ingredient and chemical composition of diets used in Exp. 1

\begin{tabular}{|c|c|c|c|c|c|c|c|c|c|}
\hline \multirow{2}{*}{$\begin{array}{l}\text { Phase } \\
\text { CP level }\end{array}$} & \multicolumn{3}{|c|}{ Grower, 25 to $55 \mathrm{~kg}$} & \multicolumn{3}{|c|}{ Finisher I, 55 to $85 \mathrm{~kg}$} & \multicolumn{3}{|c|}{ Finisher II, 85 to $110 \mathrm{~kg}$} \\
\hline & High & Medium & Low & High & Medium & Low & High & Medium & Low \\
\hline \multicolumn{10}{|l|}{ Ingredient, \% } \\
\hline Maize & 45.46 & 53.97 & 59.59 & 53.97 & 59.59 & 68.41 & 68.43 & 74.25 & 77.50 \\
\hline Wheat bran & - & - & - & - & - & - & - & 16.40 & 1.65 \\
\hline SBM, $44 \%$ & 38.40 & 30.10 & 24.70 & 30.10 & 24.70 & 16.20 & 23.40 & 1.05 & 12.60 \\
\hline Rice bran & 6.00 & 6.00 & 6.00 & 6.00 & 6.00 & 6.00 & 3.00 & 3.00 & 3.00 \\
\hline Fish meal & 2.00 & 2.00 & 2.00 & 2.00 & 2.00 & 2.00 & - & - & - \\
\hline Animal fat & 3.30 & 3.00 & 2.80 & 3.00 & 2.80 & 2.40 & - & - & - \\
\hline Molasses & 2.00 & 2.00 & 2.00 & 2.00 & 2.00 & 2.00 & 2.00 & 2.00 & 2.00 \\
\hline Tricalcium phosphate & 0.73 & 0.80 & 0.85 & 0.80 & 0.85 & 0.92 & 0.88 & 0.93 & 0.95 \\
\hline Limestone & 1.00 & 1.05 & 1.05 & 1.05 & 1.05 & 1.05 & 1.30 & 1.41 & 1.42 \\
\hline Salt & 0.28 & 0.28 & 0.28 & 0.28 & 0.28 & 0.28 & 0.28 & 0.28 & 0.28 \\
\hline Vitamin premix ${ }^{1)}$ & 0.28 & 0.28 & 0.28 & 0.28 & 0.28 & 0.28 & 0.25 & 0.25 & 0.25 \\
\hline Mineral premix ${ }^{2)}$ & 0.20 & 0.20 & 0.20 & 0.20 & 0.20 & 0.20 & 0.20 & 0.20 & 0.20 \\
\hline Choline chloride, $25 \%$ & 0.04 & 0.04 & 0.04 & 0.04 & 0.04 & 0.04 & 0.03 & 0.03 & 0.03 \\
\hline L-lysine $\cdot \mathrm{HCl}, 78 \%$ & 0.06 & 0.08 & 0.01 & 0.08 & 0.01 & 0.02 & 0.13 & 0.10 & 0.02 \\
\hline DL-methionine, $50 \%$ & 0.05 & - & - & - & - & - & - & - & - \\
\hline Probiotic & 0.10 & 0.10 & 0.10 & 0.10 & 0.10 & 0.10 & 0.10 & 0.10 & 0.10 \\
\hline Chlortetracyclin & 0.10 & 0.10 & 0.10 & 0.10 & 0.10 & 0.10 & - & - & - \\
\hline \multicolumn{10}{|c|}{ Calculated chemical composition } \\
\hline ME, kcal/kg & 3,300 & 3,300 & 3,300 & 3,300 & 3,300 & 3,300 & 3,200 & 3,200 & 3,200 \\
\hline CP, \% & 22.47 & 19.49 & 17.50 & 19.49 & 17.50 & 14.50 & 16.36 & 13.87 & 12.51 \\
\hline Lysine, \% & 1.35 & 1.15 & 0.95 & 1.15 & 0.95 & 0.75 & 0.95 & 0.75 & 0.60 \\
\hline Methionine + Cystine, \% & 0.76 & 0.66 & 0.61 & 0.66 & 0.61 & 0.53 & 0.57 & 0.51 & 0.47 \\
\hline Calcium, \% & 0.80 & 0.80 & 0.80 & 0.80 & 0.80 & 0.80 & 0.80 & 0.80 & 0.80 \\
\hline Available Phosphorus, \% & 0.30 & 0.30 & 0.30 & 0.30 & 0.30 & 0.30 & 0.25 & 0.25 & 0.25 \\
\hline
\end{tabular}

\footnotetext{
${ }^{1)}$ Supplied per kg diet: for grower and finisher I diets 8,960 IU vitamin $A, 1,680$ IU vitamin $D_{3}, 22.4 \mathrm{mg}$ vitamin $\mathrm{E}, 1.4 \mathrm{mg}$ vitamin $\mathrm{B}_{1}, 11.2 \mathrm{mg}$ vitamin $\mathrm{B}_{2}$, $2.2 \mathrm{mg}$ vitamin $\mathrm{B}_{6}, 0.042 \mathrm{mg}$ vitamin $\mathrm{B}_{12}, 1.4 \mathrm{mg}$ vitamin $\mathrm{K}_{3}$, $22.4 \mathrm{mg}$ pantothenic acid, $42 \mathrm{mg}$ niacin, $0.084 \mathrm{mg}$ biotin, $0.364 \mathrm{mg}$ folic acid. For finisher II diet 8,000 IU vitamin A, 1,500 IU vitamin $\mathrm{D}_{3}, 16 \mathrm{mg}$ vitamin $\mathrm{E}, 1.0 \mathrm{mg}$ vitamin $\mathrm{B}_{1}, 8.0 \mathrm{mg}$ vitamin $\mathrm{B}_{2}, 1.6 \mathrm{mg}$ vitamin $\mathrm{B}_{6}$, $0.03 \mathrm{mg}$ vitamin $B_{12}, 1.0 \mathrm{mg}$ vitamin $\mathrm{K}_{3}, 16 \mathrm{mg}$ pantothenic acid, $30 \mathrm{mg}$ niacin, $0.06 \mathrm{mg}$ biotin, $0.26 \mathrm{mg}$ folic acid.

${ }^{2)}$ Supplied per kg diet: 150 mg Fe, 96 mg Cu, 72 mg Zn, 46.5 mg Mn, 0.9 mg I, 0.9 mg Co, 0.3 mg Se.
} 
Table 2. Duration (days) of phase feeding regimens in Exp. 2

\begin{tabular}{ccccc}
\hline Treatment & Grower I & Grower II & Finisher I & Finisher II \\
\hline \hline T1 & 22 & 42 & 32 & 30 \\
T2 & 40 & 40 & 25 & 21 \\
T3 & 40 & 56 & 30 & - \\
\hline
\end{tabular}

II diet, 3,300 kcal/kg ME and $17.50 \% \mathrm{CP}$ for finisher I diet and 3,200 kcal $/ \mathrm{kg} \mathrm{ME}$ and $13.87 \%$ CP for finisher II diet. The ingredient and chemical compositions of experimental diets are presented in Table 3.

Both the experiments were carried out according to ethical standards and were approved by Institutional Animal Care and Use Committee of Kangwon National University. Pigs were housed in partially slotted and concrete floored pens of $2.5 \times 3.0 \mathrm{~m}$ (grower) and $3.0 \times 3.5 \mathrm{~m}$ (finisher), equipped with a self-feeder and nipple drinker to allow ad libitum access to feed and water. Pigs were weighed and feed intake was recorded at the end of each phase for the calculation of average daily gain (ADG), average daily feed intake (ADFI) and feed conversion ratio (FCR).

\section{Carcass characteristics and pork quality evaluation}

At the end of the each experiment, two barrows from each replicate reflecting average body weights were slaughtered

Table 3. Ingredient and chemical composition of diets used in Exp. $2^{1)}$

\begin{tabular}{|c|c|c|c|c|}
\hline Ingredient, \% & Grower I & Grower II & Finisher I & Finisher II \\
\hline Maize & 45.46 & 55.97 & 59.59 & 74.25 \\
\hline Wheat bran & - & - & - & 16.40 \\
\hline Soybean meal, $44 \%$ & 38.40 & 30.10 & 24.70 & 1.05 \\
\hline Rice bran & 6.00 & 6.00 & 6.00 & 3.00 \\
\hline Fish meal & 2.00 & 2.00 & 2.00 & - \\
\hline Animal fat & 3.30 & 3.00 & 2.80 & - \\
\hline Molasses & 2.00 & 2.00 & 2.00 & 2.00 \\
\hline Tricalcium phosphate & 0.73 & 0.80 & 0.85 & 0.93 \\
\hline Limestone & 1.00 & 1.05 & 1.05 & 1.41 \\
\hline Salt & 0.28 & 0.28 & 0.28 & 0.28 \\
\hline Vitamin premix ${ }^{2)}$ & 0.28 & 0.28 & 0.28 & 0.25 \\
\hline Mineral premix ${ }^{3)}$ & 0.20 & 0.20 & 0.20 & 0.20 \\
\hline Choline chloride, $25 \%$ & 0.04 & 0.04 & 0.04 & 0.03 \\
\hline L-lysine·HCl, 78\% & 0.06 & 0.08 & 0.01 & 0.10 \\
\hline DL-methionine, $50 \%$ & 0.05 & - & - & - \\
\hline Probiotic & 0.10 & 0.10 & 0.10 & 0.10 \\
\hline Chlortetracyclin & 0.10 & 0.10 & 0.10 & - \\
\hline \multicolumn{5}{|c|}{ Calculated chemical composition } \\
\hline ME, kcal/kg & 3,300 & 3,300 & 3,300 & 3,200 \\
\hline $\mathrm{CP}, \%$ & 22.47 & 19.49 & 17.50 & 13.87 \\
\hline Lysine, \% & 1.35 & 1.15 & 0.95 & 0.75 \\
\hline Methionine + cystine, \% & 0.76 & 0.66 & 0.61 & 0.51 \\
\hline Ca, \% & 0.80 & 0.80 & 0.80 & 0.80 \\
\hline Available P, \% & 0.30 & 0.30 & 0.30 & 0.25 \\
\hline \multicolumn{5}{|c|}{$\begin{array}{l}\text { 1) Treatments were: T1, fed for duration of } 22,42,32 \text { and } 30 \text { days; T2 fed for duration of } 40,40,25 \text { and } 21 \text { days with grower I, } \\
\text { grower II, finisher I and finisher II diets, respectively; whereas, T3 was fed for } 40,56 \text { and } 30 \text { days with grower I, grower II and } \\
\text { finisher I diets, respectively. } \\
\text { 2) } \\
\text { Supplied per kg diet: for grower I, II and finisher I diets } 8,960 \mathrm{IU} \text { vitamin } \mathrm{A}, 1,680 \mathrm{IU} \text { vitamin } \mathrm{D}_{3}, 22.4 \mathrm{mg} \text { vitamin } \mathrm{E}, 1.4 \mathrm{mg} \\
\text { vitamin } \mathrm{B}_{1}, 11.2 \mathrm{mg} \text { vitamin } \mathrm{B}_{2}, 2.2 \mathrm{mg} \text { vitamin } \mathrm{B}_{6}, 0.042 \mathrm{mg} \text { vitamin } \mathrm{B}_{12}, 1.4 \mathrm{mg} \text { vitamin } \mathrm{K}_{3}, 22.4 \mathrm{mg} \text { pantothenic acid, } 42 \mathrm{mg} \\
\text { niacin, } 0.084 \mathrm{mg} \text { biotin, } 0.364 \mathrm{mg} \text { folic acid. For finisher II diet } 8,000 \mathrm{IU} \text { vitamin A, } 1,500 \mathrm{IU} \text { vitamin } \mathrm{D}_{3} \text {, } 16 \mathrm{mg} \text { vitamin E, } 1.0 \\
\text { mg vitamin } \mathrm{B}_{1}, 8.0 \mathrm{mg} \text { vitamin } \mathrm{B}_{2}, 1.6 \mathrm{mg} \text { vitamin } \mathrm{B}_{6}, 0.03 \mathrm{mg} \text { vitamin } \mathrm{B}_{12}, 1.0 \mathrm{mg} \text { vitamin } \mathrm{K}_{3}, 16 \mathrm{mg} \text { pantothenic acid, } 30 \mathrm{mg} \\
\text { niacin, } 0.06 \mathrm{mg} \text { biotin, } 0.26 \mathrm{mg} \text { folic acid. }\end{array}$} \\
\hline
\end{tabular}


by electrical stunning and exsanguination at a commercial slaughter house. The hot carcass weight was measured and used to calculate the dressing percentage by the following equation: (hot carcass weight/ final live weight) $\times 100$. Back fat thickness was determined at the $10^{\text {th }}$ rib.

After overnight chilling of carcass, the right longissmus dorsi muscle was removed and sectioned into $2.54 \mathrm{~cm}$ chops for the measurement of pork quality. These chops were subjectively evaluated for color score and marbling according to the 5-point descriptive scale by National Pork Producers Council (1991). Chops were then vacuum packed and stored at $4{ }^{\circ} \mathrm{C}$ for 5 and 10 days for the analysis of Commission Internationale de L'Eclairage (CIE) color score, drip loss and thiobarbituric acid reactive substances (TBARS).

The lightness $\left(\mathrm{L}^{*}\right)$, redness $\left(\mathrm{a}^{*}\right)$, and yellowness $\left(\mathrm{b}^{*}\right)$ color values were measured using color difference meter (Yasuda Seiko Co., CR-310, Minolta, Tokyo, Japan) at day 0, and days 5 and 10 of vacuum storage by using the standard method of CIE. Drip loss was determined by the method of Kauffman et al. (1986) and lipid peroxidation was measured by TBARS assay as per the method of Sinnhuber and Yu (1977).

\section{Statistical analyses}

Data generated was subjected to statistical analysis using SAS statistical software package. The pens were the experimental units for the analysis of growth performance while the individual pig was the experimental unit for the analysis of carcass characteristics and pork. In both the experiments the data was analyzed by using ANOVA and when significant differences were noted, the means were compared using LSD's multiple range tests. The level of significance was accepted at $\mathrm{P}<0.05$.

\section{RESULTS AND DISCUSSION}

\section{Growth performance}

In Exp. 1, feeding of HP, MP or LP diets had no influence on the performance of pigs during grower period (Table 4). During finisher I phase, pigs fed MP diet had greater $(\mathrm{P}<0.05) \mathrm{ADG}$ and $\mathrm{ADFI}$ when compared with pigs offered HP and LP diets, while during the finisher II phase, pigs fed MP and LP diets had greater ADG than pigs fed HP diet $(\mathrm{P}<0.05 ; 900$ and 898 vs. $867 \mathrm{~g})$. In addition, during finisher II phase, pigs fed MP diet consumed less feed (2,637 vs. 2,959 and 3,047 g), and had better FCR (2.93 vs. 3.41 and 3.40) when compared with pigs fed HP and LP diets, respectively. When the whole experimental period was considered, pigs offered MP diet showed higher $(\mathrm{P}<0.05)$ ADG and better FCR than pigs fed LP diet; however, there were no differences in the overall performance between pigs fed HP and MP diets.

Table 4. Effect of CP levels on growth performance of growing-finishing pigs (Exp. 1)

\begin{tabular}{|c|c|c|c|c|}
\hline \multirow{2}{*}{ Item } & \multicolumn{3}{|c|}{ CP level $^{\mathrm{I}}$} & \multirow{2}{*}{$\mathrm{SE}^{2)}$} \\
\hline & High & Medium & Low & \\
\hline \multicolumn{5}{|c|}{ Grower (25 to 55 kg) } \\
\hline ADG, g & 746 & 764 & 724 & 34.15 \\
\hline ADFI, g & 1.625 & 1.634 & 1.649 & 108.13 \\
\hline FCR & 2.16 & 2.14 & 2.32 & 0.12 \\
\hline \multicolumn{5}{|c|}{ Finisher I (55 to 85 kg) } \\
\hline ADG, $g$ & $847^{\mathrm{b}}$ & $969^{a}$ & $815^{\mathrm{b}}$ & 40.82 \\
\hline ADFI, g & $2.556^{\mathrm{b}}$ & $2.945^{\mathrm{a}}$ & $2.607^{\mathrm{b}}$ & 162.38 \\
\hline FCR & 3.02 & 3.04 & 3.20 & 0.21 \\
\hline \multicolumn{5}{|c|}{ Finisher II (85 to $110 \mathrm{~kg}$ ) } \\
\hline ADG, g & $867^{\mathrm{b}}$ & $900^{\mathrm{a}}$ & $898^{\mathrm{a}}$ & 70.33 \\
\hline ADFI, g & $2.959^{\mathrm{a}}$ & $2.637^{\mathrm{b}}$ & $3.047^{\mathrm{a}}$ & 153.11 \\
\hline FCR & $3.41^{\mathrm{a}}$ & $2.93^{\mathrm{b}}$ & $3.40^{\mathrm{a}}$ & 0.27 \\
\hline \multicolumn{5}{|c|}{ Overall (25 to $110 \mathrm{~kg}$ ) } \\
\hline ADG, $g$ & $814^{\mathrm{ab}}$ & $860^{\mathrm{a}}$ & $801^{\mathrm{b}}$ & 35.29 \\
\hline ADFI, g & 2.304 & 2.311 & 2.358 & 126.99 \\
\hline FCR & $2.84^{\mathrm{ab}}$ & $2.69^{b}$ & $2.94^{\mathrm{a}}$ & 0.15 \\
\hline
\end{tabular}

\footnotetext{
${ }^{\mathrm{ab}}$ Means with different superscripts in the same row differ significantly $(\mathrm{P}<0.05)$.

${ }^{1)}$ Dietary CP levels were: High, 22.47-19.49-16.36\%; medium, 19.49-17.50-13.87\% and low, $17.50-14.50-12.51 \%$ for grower-finisher Ifinisher II diets, respectively.

2) Standard error.
} 
Kim et al. (2000a) investigated the growth performance of growing crossbred pigs fed diets containing different CP levels (18-18; 18-16; 19-17\%) during early-late growing period, respectively, and did not find any significant effect of dietary treatments on the performance of pigs. Further, Kim et al. (2000b) studied the effects of different CP diets (16-16; 16-14; 17-15\%) during early-late finishing period and found that within the same sex different dietary protein levels had no effect on the growth performance. From these studies they suggested the optimum sequence of $18-16 \%$ CP for early-late growing periods (Kim et al., 2000a), and 1614\% CP for early-late finishing period (Kim et al., 2000b). A series of experiments conducted by Lee et al. (2000; 2001a) to determine the optimal number of phases for finishing period and evaluate effects of CP levels and phase feeding regimens on the growth performance of finishing pigs revealed that the number of phases has no effect on performance of finishing pigs; however, they suggested 16$14-12 \%$ dietary CP to be advantages in the sense of economics and environment. The results of our study demonstrate that the MP level (19.45-17.50-13.87\%) during grower-finisher I-finisher II phases, respectively, is optimum for growing-finishing pigs. Moreover, diets with CP in excess of $14 \%$ for late finishing pigs did not show any improvements in growth rate (Han et al., 1998). Also previous reports have proved that pigs do not have the ability to control protein intake to meet their requirements (Owen et al., 1994; Nam and Aherne, 1995), and consumption of protein above requirement leads to wastage as the animal is unable to convert dietary amino acids to body protein (Chen et al., 1996). Thus, use of adequate protein level in diet can save the protein sources.

In Exp. 2, different duration and number of phase feeding regimens had no influence on the performance of growingfinishing pigs (Table 5). Similar to our findings, Ko et al.
(2003), who from their four week study had reported that phase feeding of diets for different duration, did not have any effect on the growth performance of pigs.

\section{Carcass characteristics and pork quality evaluation}

The effect of dietary CP levels on carcass characteristics and pork quality in growing finishing pigs in Exp. 1 is presented in Table 6 . The dressing percentage and back fat thickness were found to be comparable among the dietary treatments. Marbling score was higher $(\mathrm{P}<0.05)$ in pigs fed MP and LP diets demonstrating that dietary protein influenced the intramuscular fat (IMF). This result is consistent with other studies which have indicated that IMF content is increased by feeding low lysine or proteindeficient diets throughout the growing and/or finishing phases (Bidner et al., 2004; Wood et al., 2004). Inadequate dietary protein and lysine limits protein synthesis and increases the amount of energy available for fat deposition resulting in higher fat deposition in muscle.

Meat from pigs fed HP diet had lower $(\mathrm{P}<0.05)$ subjective color score than meat obtained from pigs fed LP diet (Table 6) suggesting that meat of pigs fed LP diet is darker and this may partly be attributed to the higher IMF content. Our findings agree with the findings of Latorre et al. (2003), who illustrated that increased IMF content was associated with more intense muscle color. The TBARS values at day 0 were not influenced by the dietary $\mathrm{CP}$; however, at days 5 and 10 of storage, loins from pigs fed HP and MP diets had less $(\mathrm{P}<0.05)$ TBARS values than loins of pigs fed LP diet. At 0,5 and 10 days of storage the loins obtained from pigs fed LP diet exhibited greater $(\mathrm{P}<0.05)$ drip loss while loins of pigs fed MP diet had the least drip loss. Contrary to the findings of our study, previous researchers did not find any effect of dietary protein on drip loss (Goerl et al.,

Table 5. Effect of duration and number of phase feeding regimens on the growth performance of growingfinishing pigs (Exp. 2) ${ }^{1)}$

\begin{tabular}{lcccr}
\hline Item & T1 & T2 & T3 & SE $^{2)}$ \\
\hline \hline Initial BW, kg & 10.37 & 10.06 & 10.59 & 1.64 \\
Final BW, kg & 115.00 & 114.00 & 115.50 & 9.79 \\
ADG, g & 830 & 820 & 830 & 29.90 \\
ADFI, g & 2.170 & 2.110 & 2.160 & 101.62 \\
FCR & 2.61 & 2.57 & 2.60 & 0.07 \\
\hline
\end{tabular}

\footnotetext{
${ }^{1)}$ Treatments were: T1, fed for duration of 22, 42, 32 and 30 days and T2 fed for duration of 40,40, 25 and 21 days with grower I, grower II, finisher I and finisher II diets, respectively; whereas, T3 was fed grower I, grower II and finisher I diets for 40 , 56 and 30 days, respectively.

2) Standard error.
} 
Table 6. Effect of CP levels on carcass characteristics and pork quality in growing-finishing pigs (Exp. 1)

\begin{tabular}{|c|c|c|c|c|}
\hline \multirow{2}{*}{ Item } & \multicolumn{3}{|c|}{ CP level $^{1)}$} & \multirow{2}{*}{$\mathrm{SE}^{2)}$} \\
\hline & High & Medium & Low & \\
\hline Dressing, \% & 77.81 & 76.77 & 78.71 & 4.58 \\
\hline Backfat thickness, mm & 18.86 & 20.19 & 20.24 & 3.98 \\
\hline Marbling score ${ }^{3)}$ & $1.25^{\mathrm{b}}$ & $1.75^{\mathrm{a}}$ & $1.67^{\mathrm{a}}$ & 0.36 \\
\hline Pork color score ${ }^{4)}$ & $2.25^{\mathrm{b}}$ & $2.58^{\mathrm{ab}}$ & $2.67^{\mathrm{a}}$ & 0.29 \\
\hline \multicolumn{5}{|l|}{ TBARS, mg/kg } \\
\hline day 0 & 0.91 & 0.90 & 0.84 & 0.44 \\
\hline day 5 & $4.18^{\mathrm{b}}$ & $4.83^{\mathrm{b}}$ & $6.59^{\mathrm{a}}$ & 1.60 \\
\hline day 10 & $4.61^{\mathrm{b}}$ & $5.21^{\mathrm{b}}$ & $7.15^{\mathrm{a}}$ & 1.52 \\
\hline \multicolumn{5}{|l|}{ Drip loss, \% } \\
\hline day 0 & $3.13^{\mathrm{ab}}$ & $2.21^{\mathrm{b}}$ & $3.68^{\mathrm{a}}$ & 0.81 \\
\hline day 5 & $8.25^{\mathrm{b}}$ & $5.58^{\mathrm{C}}$ & $9.58^{\mathrm{a}}$ & 1.85 \\
\hline day 10 & $11.22^{\mathrm{a}}$ & $8.07^{\mathrm{b}}$ & $10.49^{\mathrm{ab}}$ & 1.87 \\
\hline \multicolumn{5}{|l|}{ CIE color score } \\
\hline \multicolumn{5}{|l|}{ Lightness, L* } \\
\hline day 0 & $55.86^{\mathrm{ab}}$ & $56.46^{\mathrm{a}}$ & $54.44^{\mathrm{b}}$ & 2.66 \\
\hline day 5 & $58.38^{\mathrm{a}}$ & $57.92^{\mathrm{a}}$ & $55.67^{\mathrm{b}}$ & 2.94 \\
\hline day 10 & 58.98 & 58.11 & 56.28 & 2.33 \\
\hline \multicolumn{5}{|l|}{ Redness, a* } \\
\hline day 0 & $6.67^{\mathrm{b}}$ & $8.12^{\mathrm{a}}$ & $5.59^{c}$ & 1.66 \\
\hline day 5 & 7.25 & 8.29 & 7.92 & 1.69 \\
\hline day 10 & 7.02 & 7.55 & 6.64 & 1.34 \\
\hline \multicolumn{5}{|l|}{ Yellowness, b* } \\
\hline day 0 & 4.91 & 5.69 & 4.52 & 1.18 \\
\hline day 5 & 8.18 & 8.02 & 9.19 & 1.97 \\
\hline day 10 & 8.70 & 8.79 & 9.01 & 1.34 \\
\hline
\end{tabular}

a,b,c Means with different superscripts in the same row differ significantly $(\mathrm{P}<0.05)$.

${ }^{1)}$ Dietary CP levels were: High, 22.47-19.49-16.36\%; medium, 19.49-17.50-13.87\% and low, $17.50-14.50-12.51 \%$ for grower-finisher Ifinisher II diets, respectively.

2) Standard error.

3) Scored on the scale of $1=$ practically devoid to $5=$ very firm and dark (NPPC, 1991).

4) Scored on the scale of $1=$ pale pinkish grey to $5=$ dark purplish red (NPPC, 1991).

1995; Cisneros et al., 1996; Witte et al., 2000).

Loins obtained from pigs fed LP diet had lowest CIE L* color score values at days 0 and 5 . The CIE $a^{*}$ values at day 0 were highest $(\mathrm{P}<0.05)$ in meat of pigs fed MP diet and lowest in pigs fed LP diet while the CIE $a^{*}$ values at days 5 and 10, and CIE b* values (days 0, 5 and 10) remained unaffected by dietary $\mathrm{CP}$ levels. The lower CIE $\mathrm{L}^{*}$ and $\mathrm{a}^{*}$ values in meat of pigs fed LP diet indicate that the meat is darker and less red in color. These findings are in contradiction with those of Bidner et al. (2004) who had observed greater $\mathrm{L}^{*}$ values in meat of pigs fed low lysine diets. Moreover, Goerl et al. (1995) had also reported greater $a^{*}$ and $b^{*}$ values in meat obtained from pigs fed low-protein diets. These discrepancies in the findings may be attributed to the lysine and amino acid compositions of the diets.

Table 7 summarizes the effects of different duration and number of phase feeding regimens on the carcass characteristics and pork quality of pigs in Exp. 2. The dressing percent, backfat thickness, color and marbling score were not influenced by different durations of phase feeding regimens. Likewise, TBARS, drip loss and CIE color score ( $\mathrm{L}^{*}, \mathrm{a}^{*}$ and $\left.b^{*}\right)$ of loins at different storage intervals also did not differ among the treatments. These findings agree with those of Han et al. (1998), who also did not notice any differences in the carcass characteristics of pigs under different phase feeding regimens. However, two phase feeding system was reported to significantly reduce the backfat thickness than three phase feeding system (Ko et al., 2004), whereas, Lee et 
Table 7. Effect of duration and number of phase feeding regimens on the carcass characteristics and pork quality of growing-finishing pigs (Exp. 2) ${ }^{1)}$

\begin{tabular}{|c|c|c|c|c|}
\hline Item & $\mathrm{T} 1$ & $\mathrm{~T} 2$ & T3 & $\mathrm{SE}^{2)}$ \\
\hline Dressing, \% & 67.44 & 68.76 & 67.51 & 1.60 \\
\hline Backfat thickness, mm & 17.70 & 16.95 & 18.30 & 4.45 \\
\hline Marbling score ${ }^{3)}$ & 1.42 & 1.58 & 1.67 & 0.15 \\
\hline Pork color score ${ }^{4)}$ & 2.42 & 2.50 & 2.58 & 0.16 \\
\hline \multicolumn{5}{|l|}{ TBARS, $\mathrm{mg} / \mathrm{kg}$} \\
\hline day 0 & 0.92 & 0.74 & 0.82 & 0.41 \\
\hline day 5 & 4.64 & 4.61 & 5.64 & 1.38 \\
\hline day 10 & 5.33 & 5.04 & 5.93 & 1.16 \\
\hline \multicolumn{5}{|l|}{ Drip loss, \% } \\
\hline day 0 & 3.46 & 3.33 & 3.72 & 0.42 \\
\hline day 5 & 7.29 & 7.51 & 7.73 & 1.26 \\
\hline day 10 & 9.85 & 9.89 & 10.78 & 1.07 \\
\hline
\end{tabular}

\section{CIE color score}

Lightness, L*

\begin{tabular}{|c|c|c|c|c|}
\hline & & & & \\
\hline day 0 & 55.72 & 54.64 & 55.30 & 2.33 \\
\hline day 5 & 55.14 & 51.27 & 53.48 & 3.94 \\
\hline day 10 & 55.94 & 54.50 & 54.57 & 2.98 \\
\hline \multicolumn{5}{|l|}{ Redness, $a^{*}$} \\
\hline day 0 & 17.47 & 18.11 & 16.41 & 4.98 \\
\hline day 5 & 17.29 & 16.24 & 16.48 & 1.97 \\
\hline day 10 & 14.09 & 13.99 & 12.77 & 5.04 \\
\hline \multicolumn{5}{|l|}{ Yellowness, b* } \\
\hline day 0 & 7.48 & 6.55 & 8.00 & 1.23 \\
\hline day 5 & 7.03 & 6.55 & 7.40 & 1.11 \\
\hline day 10 & 7.51 & 7.85 & 8.17 & 1.22 \\
\hline
\end{tabular}

${ }^{1)}$ Treatments were: T1, fed for duration of 22, 42, 32 and 30 days and T2 fed for duration of 40, 40, 25 and 21 days with grower I, grower II, finisher I and finisher II diets, respectively; whereas, T3 was fed grower I, grower II and finisher I diets for 40, 56 and 30 days, respectively.

2) Standard error.

3) Scored on the scale of $1=$ practically devoid to $5=$ very firm and dark (NPPC, 1991).

4) Scored on the scale of $1=$ pale pinkish grey to $5=$ dark purplish red (NPPC, 1991).

al. (2000) had observed a reduction in the backfat thickness with an increase in the number of feeding regimens.

Thus, form these results it can be concluded that both high (22.47-19.49-16.36\%) as well as low (17.50-14.50-12.51 $\%)$ dietary protein levels in three phase feeding regimen resulted in poorer performance and pork quality; however, alterations in the duration and number of phase feeding regimens do not have any discernible effect on the performance and pork quality. In addition, medium (19.49$17.50-13.87 \%$ ) protein level in three phase feeding system may be recommended for obtaining better performance and pork quality.

\section{ACKNOWLEDGEMENTS}

The authors sincerely acknowledge for the partial financial support provided by the Institute of Animal Resources at Kangwon National University, Chuncheon, Republic of Korea.

\section{REFERENCES}

Bidner, B. S., Ellis, M., Witte, D. P., Carr, S. N. and McKeith, F. K. 2004. Influence of dietary lysine level, pre-slaughter fasting, rendement napole genotype on fresh pork quality. Meat Sci. 68:53-60.

Chen, H. Y., Lewis, A. J. and Miller, P. S. 1996. The effects of dietary protein concentration on performance and visceral organ mass in finishing barrows and gilts. 1996 Nebraska Swine Report. pp. 25-27.

Cisneros, F., Ellis, M., Baker, D. H., Easter, R. A. and McKeit,h F. K. 1996. The influence of short-term feeding of amino acid- 
deficient diets and high dietary leucine levels on the intramuscular fat content of pig muscle. Anim. Sci. 63:517522.

Goerl, K. F., Eilert, S. J., Mandigo, R. W., Chen, H. Y. and Miller, P. S. 1995. Pork characteristics as affected by two populations of swine and six crude protein levels. J. Anim. Sci. 73:3621-3626

Han, I. K., Lee, J. H., Piao, X. S. and Defa, L. 2001. Feeding and management system to reduce environmental pollution in swine production - review. Asian-Aust. J. Anim. Sci. 14:432444.

Han, I. K., Kim, J. H., Chu, K. S., Xuan, Z. H., Sohn, K. S. and Kim, M. K. 1998. Effect of phase feeding on the growth performance and nutrient utilization in finishing pigs. AsianAust. J. Anim. Sci. 11:559-565.

Kauffman, R. G., Eikelenboom, G., van der Wal, P. G., Merkus, G. and Zaar, M. 1986. The use of filter paper to estimate drip loss of porcine musculature. Meat Sci. 18:191-200.

Kim, Y. G., Jin, J., Kim, J. D., Kim, J. H. and Han, I. K. 2000a. Effects of phase feeding on growth performance, nutrient digestibility and nutrient excretion of growing boars and gilts. Asian-Aust. J. Anim. Sci. 13:795-801.

Kim, Y. G., Jin, J., Kim, J. D., Shin, I. S. and Han, I. K. 2000b. Effects of phase feeding on growth performance, nutrient digestibility, nutrient excretion and carcass characteristics of finishing barrows and gilt. Asian-Aust. J. Anim. Sci. 13:802810.

Ko, T. G., Lee, J. H., Kim, B. G., Min, T. S., Cho, S. B., Han, I. K. and Kim, Y. Y. 2004. Effects of phase feeding and sugar beet pulp on growth performance, nutrient digestibility, blood urea nitrogen, nutrient excretion and carcass characteristics in finishing pigs. Asian-Aust. J. Anim. Sci. 17:1150-1157.

Ko, T. G., Lee, J. H., Min, T. S., Kim, Y. Y. and Han, I. K. 2003. Study on the development of the optimum feeding regimen for pigs weaned at 21 days of age. Asian-Aust. J. Anim. Sci. 16:1518-1523.

Kyriazakis, I., Emmans, G. C. and Whittemore, C. T. 1990. Diet selection in pigs: choices made by growing pigs given food of different protein contents. Anim. Prod. 51:189-199.

Latorre, M. A., Lazaro, R., Gracia, M. I., Nieto, M. and Mateos, G. G. 2003. Effect of sex and terminal sire genotype on performance, carcass characteristics and meat quality of pigs slaughtered at $117 \mathrm{~kg}$ body weight. Meat Sci. 65:1369-1377.
Lawrie, R. A. 1991. Meat Science. 5th ed. Pergamon Press, London.

Lee, J. H., Kim, J. D., Kim, J. H., Kim, I. H. and Han, I. K. 2001a. Effects of different dietary CP levels on the growth, nutrient utilization and carcass characteristics of finishing borrows and gilts reared in phase feeding regimen. J. Appl. Anim. Res. 19:145-163.

Lee, J. H., Kim, J. D., Kim, J. H., Jin, J. and Han, I. K. 2000. Effect of phase feeding on the growth performance, nutrient utilization and carcass characteristics in finishing pigs. AsianAust. J. Anim. Sci. 8:1137-1146.

Lee, J. H., Kim, J. H., Kim, J. D., Kim, S. W. and Han, I. K. 2001b. Effects of low crude protein diets supplemented with synthetic amino acids on performance, nutrient utilization and carcass characteristics in finishing pigs reared using a phase feeding regimen. Asian-Aust. J. Anim. Sci. 14:655-667.

Nam, D. S. and Aherne, F. X. 1995. A comparison of choice and phase feeding for growing-finishing pigs. Can. J. Anim. Sci. 75:93-98.

NPPC. 1991. Procedures to Evaluate Market Hogs. 3rd ed. National Pork Producers Council, Des Moines, IA.

NRC. 1998. Nutrient Requirements of Swine. 10th ed. National Academy Press, Washington, DC.

Owen, K. Q., Knabe, D. A., Burgoon, K. G. and Gregg, E. J. 1994. Self-selection of diets and lysine requirements of growing-finishing swine. J. Anim. Sci. 72:554-564.

Sinnhuber, R. O. and Yu, T. C. 1977. The 2-thiobarbituric acid reaction, an objective measure of the oxidative determination occurring in fats and oils. J. Jan. Soc. Fish Sci. 26:259-267.

Sutton, A. L., Kephardt, K. B., Patterson, J. A., Mumma, R., Kelly, D. T., Bogus, E., Jones, D. D. and Heber, A. 1996. Manipulating swine diets to reduce ammonia and odor emissions. Proceedings of the 1st International Conference on Air Pollution from Agricultural Operations, pp. 445-452.

Witte, D. P., Ellis, M., McKeith, F. K. and Wilson, E. R. 2000. Effect of dietary lysine level and environmental temperature during the finishing phase on the intramuscular fat content of pork. J. Anim. Sci. 78:1272-1276.

Wood, J. D., Nute, G. R., Richardson, R. I., Whittington, F. M., Southwood, O., Plastow, G., Mansbridge, R., Costa, N. D. and Chang, K. C. 2004. Effects of breed, diet and muscle on fat deposition and eating quality in pigs. Meat Sci. 67:651-667.

(Received March 6, 2010; Revised May 31, 2010; Accepted May 31, 2010) 